\title{
Buttock claudication: what induces pain only in the left buttock on every movement?
}

\author{
Masaki Tago, ${ }^{\circledR}$ Risa Hirata, Yoshimasa Oda, Naoko E Katsuki
}

Department of General Medicine, Saga University Hospital, Saga, Japan

Correspondence to Dr Masaki Tago, tagomas@cc.saga-u.ac.jp

Accepted 16 June 2019

\section{DESCRIPTION}

An 89-year-old man presented with a 3-day history of pain in the left buttock with every movement. He felt pain whenever he moved, including when standing up or walking. Although this prevented him from walking, the pain disappeared at rest. $\mathrm{He}$ had a history of arteriosclerotic diseases including arteriosclerosis obliterans and cerebral infarction, but he had no history of trauma. He had undergone pacemaker implantation to treat a complete atrioventricular block. Physical examination revealed no tenderness or skin lesions in the left buttock and no signs of nerve root compression. Laboratory examination revealed an elevated D-dimer concentration of $1.24 \mu \mathrm{g} / \mathrm{mL}$. A plain pelvic radiograph showed no findings of osteoarthritis or bone fractures. Therefore, we performed CT with contrast enhancement to identify vascular abnormalities, especially around his left buttock.

CT revealed occlusion of the left superior gluteal artery with severe systemic arteriosclerotic changes (figure 1A-C). Therefore, the patient was diagnosed with left buttock claudication due to occlusion of the left superior gluteal artery. Site of occlusion was rather peripheral and collateral circulation was marginally preserved, though the superior gluteal artery is a terminal branch of internal iliac artery, we treated him conservatively. We chose an oral anticoagulant because paroxysmal atrial fibrillation had been revealed on his pacemaker record.

Buttock claudication is caused by occlusion of the internal iliac artery or its branches, preventing


Figure 1 Abdominal CT with contrast enhancement. (A) Axial view, (B) enlarged axial view and (C) threedimensional image of the arteries. The site of occlusion was the left superior gluteal artery ( $A$ and $B$, arrows; $C$, circle). The low-density area in the enlarged axial view was suspected to be a thrombus ( $B$, arrowhead).

\section{Learning points}

- Buttock claudication is caused by occlusion of the internal iliac artery or its branches.

- Buttock claudication can be a diagnostic challenge because of the lack of ischaemic symptoms in the legs or a low Ankle-Brachial Index.

- Buttock claudication must be considered when seeing a patient with exertional pain in the buttock.

gluteal blood flow. ${ }^{1}$ Although the most common cause is vascular surgery involving the internal iliac artery, arteriosclerosis or thrombosis can also cause buttock claudication. ${ }^{1}$ Angiography and CT with contrast enhancement are useful for a definitive diagnosis. However, buttock claudication can be a diagnostic challenge, and it may be misdiagnosed as an orthopaedic disease because of the lack of ischaemic symptoms in the legs or a low Ankle-Brachial Index. $^{2}$

An understanding of the vascular anatomy is imperative to achieving a correct diagnosis of buttock claudication. Recognition of ischaemic lesions of gluteal muscle claudication as the cause of buttock claudication could enable a rapid and correct diagnosis. Furthermore, buttock claudication must be considered when seeing a patient with exertional pain in the buttock.

Acknowledgements The authors thank Angela Morben, DVM, ELS, from Edanz Group (www.edanzediting.com/ac), for editing a draft of this manuscript.

Contributors MT: literature search, study conception and manuscript drafting. RH: literature search, manuscript drafting and clinical care of the patient. YO: literature search and clinical care of the patient. NEK: study conception and manuscript revision.

Funding The authors have not declared a specific grant for this research from any funding agency in the public, commercial or not-for-profit sectors.

Competing interests None declared.

Patient consent for publication Obtained.

Provenance and peer review Not commissioned; externally peer reviewed.

\section{REFERENCES}

1 Batt M, Baque J, Bouillanne PJ, et al. Percutaneous angioplasty of the superior gluteal artery for buttock claudication: a report of seven cases and literature review. J Vasc Surg 2006;43:987-91.

2 Mahé G, Kaladji A, Le Faucheur A, et al. Internal iliac artery stenosis: diagnosis and how to manage it in 2015. Front Cardiovasc Med 2015;2:33. 
Images in...

Copyright 2019 BMJ Publishing Group. All rights reserved. For permission to reuse any of this content visit https://www.bmj.com/company/products-services/rights-and-licensing/permissions/

BMJ Case Report Fellows may re-use this article for personal use and teaching without any further permission.

Become a Fellow of BMJ Case Reports today and you can:

- Submit as many cases as you like

- Enjoy fast sympathetic peer review and rapid publication of accepted articles

Access all the published articles

Re-use any of the published material for personal use and teaching without further permission

Customer Service

If you have any further queries about your subscription, please contact our customer services team on +44 (0) 2071111105 or via email at support@bmj.com.

Visit casereports.bmj.com for more articles like this and to become a Fellow 